\title{
Learning to Love the Unknown
}

\section{Chinese-Indonesian Contributions to Nation Building}

\author{
Tom Hoogervorst \\ KITLV/Royal Netherlands Institute of Southeast Asian and Caribbean Studies \\ hoogervorst@kitlv.nl
}

Leo Suryadinata and Didi Kwartanada (eds.), Tionghoa dalam Keindonesiaan. Peran dan Kontribusi bagi Pembangunan Bangsa. Jilid I. Jakarta: Yayasan Nabil, 2016, xxxvii + 469 pp. ISBN 9789791873079 .

Leo Suryadinata and Didi Kwartanada (eds.), Tionghoa dalam Keindonesiaan. Peran dan Kontribusi bagi Pembangunan Bangsa. Jilid II.Jakarta:Yayasan Nabil, 2016, xxxvii + 426 pp. ISBN 9789791873079 .

Leo Suryadinata and Didi Kwartanada (eds.), Tionghoa dalam Keindonesiaan. Peran dan Kontribusi bagi Pembangunan Bangsa. Jilid III. Jakarta: Yayasan Nabil, 2016, xxxvii +467 pp. ISBN 9789791873079 . The three volumes must be purchased together and can be ordered with the publisher, at sekretariat@ nabilfoundation.org. Price: ID R 1,500,000 (paperback).

\section{Wajibing jalma tumuwuh \\ Padha sunga trima kasih \\ Marang sakabehing Cina \\ Denira gung mitulungi}

('Every human being

ought to be grateful

to all Chinese

for their never-failing help')

Apdul Mutalip, second half of the nineteenth century

VAN DER MOLEN 2017:416

'Another book about the Chinese of Indonesia?', asks Eddie Lembong aloud (p. xi). As the founder of Yayasan Nabil, an organization established to promote nation-building through cultural cross-fertilization (vol. 3, p. 429), Lem-

(C) TOM HOOGERVORST, 2017 | DOI: $10.1163 / 22134379-17302007$

This is an open access article distributed under the terms of the prevailing CC-BY-NC license 
bong has been the main driving force behind the long-awaited three-volume publication here under review: Tionghoa dalam Keindonesiaan: Peran dan kontribusi bagi pembangunan bangsa (rough translation: 'The Chinese in Indonesian identity: Their Role and Contribution to Nation-building').

Indeed, the past three years have seen a notable upsurge of Indonesian pulications focusing on the country's Chinese minority. Some books have found their way into specialized international libraries (Santosa 2014, Mastuti 2014, Jusuf 2014, Moerany 2014, Oesman 2015), but most suffered from small print runs, rarely made it abroad, and quickly disappeared from Indonesian bookstores-making it frustratingly difficult for the non-resident researcher to access them or know about their existence in the first place. Indonesia's academic landscape is experiencing an equally prolific 'Chinese turn'. After an orchestrated silence during Soeharto's New Order regime (1966-1998) on the contributions of ethnic Chinese to the history of the archipelago, followed by disappointingly sluggish improvements in the ensuing Reformasi period, scholarly work on Chinese-Indonesian history is now thriving-as evidenced most recently by the publication of a two-volume special edition of Jurnal Wacana titled 'Chinese Indonesians in historical perspective' (Vol. 18, No. 1 and 2, 2017).

Returning to the initial question, why was this three-volume series written? In his introductory statement (pp. xi-xxi), Lembong argues that the Chinese have disappeared from Indonesia's national history, with their contributions to the nation's language, press, printed media, and other arenas often left unacknowledged in history books. Despite more than a millennium of intensive contacts and migrations between the areas now known as China and Indonesia, the Chinese continue to be seen as the Other (liyan), rather than part of the innumerable communities that constitute the rich fabric of Indonesia's ethnic diversity. As a result, many Chinese Indonesians have concealed their ethnic heritage or drifted away from it in order to fit in. The present project, we are repeatedly assured, was never intended to be an exercise in self-glorification. Rather, it is a plea to accept the Chinese as an integral part of Indonesia, a demographic segment that has contributed to its history and culture-and continues to do so. The books make a conscious effort to familiarize a broad range of readers with a community widely and stereotypically perceived to be economically privileged, of questionable loyalty, and either politically aloof or bent on dominating Indonesian politics. It goes without saying that a significant number of Indonesians recognized as indigenous (pribumi) is sympathetic to their ethnic Chinese compatriots, yet thus far this has hardly led to any major changes in the way history is taught or the national curriculum is shaped. 
Had this book come out a couple of months later, the editors could have substantiated their case by calling attention to the hot-button issue of antiChinese sentiments during Jakarta's latest gubernatorial elections, in which the incumbent and now defeated candidate, Basuki 'Ahok' Tjahaja Purnama, faced racial slurs, unfounded yet enduring accusations of pro-Beijing agency, and the mind-boggling charge of blasphemy followed by his imprisonment. During the campaigning period, his challenger Anies Baswedan incorrectly suggested that the Chinese played no role in Indonesia's independence struggle. While the Indonesian brand of Sinophobia can be characterized as a selectively enforced rhetorical device rather than a coherent ideology, the oft-repeated equation of aseng ('ethnic Chinese') with asing ('foreign') has nonetheless proven to be a consistent trope and - in some circles-a dominant narrative. In this light, there could have been no better time for Tionghoa dalam Keindonesiaan to come out. As the preface suggests (p. xiii), 'the unknown is unloved' (tak kenal maka tak sayang); nation-building is destined to fail if a vital part of a nation is perceived as not belonging inside its borders. Here, the philosophy of Yayasan Nabil clearly echoes through the book's introductory pages.

Aptly supervised by editor-in-chief Leo Suryadinata and managing editor Didi Kwartanada, and with forewords by Eddie Lembong and Yudi Latif, the book is a remarkably exhaustive standard work on Indonesia's Chinese diaspora, surpassing most, if not all, earlier scholarship. While the editors do not label their work an encyclopedia, it is encyclopedic in its size and coverage, amounting to a total of around 1400 pages. By comparison, The Encyclopedia of the Chinese Overseas (Pan 1999) consists of 399 pages and the Routledge Handbook of the Chinese Diaspora (Tan 2013) is 512. Many of the book's 73 authors have had long and productive careers, but early-career scholars have also been welcomed into their ranks. Of the 129 papers that tie together the three volumes, Leo Suryadinata has contributed an impressive 26. Multiple contributions were also made by other familiar figures in the field of ChineseIndonesian Studies, including Didi Kwartanada, Myra Sidharta, Yerry Wirawan, Dédé Oetomo, and Maxensius Tri Sambodo. The diverse chapters complement each other and are extensively cross-referenced. Some of them focus on broad themes, while others zoom in on particular individuals. Each volume comes with the same introductory notes (pp. i-xxxvii). The indexes are volume-specific and consist of an index of persons and one of 'organizations, companies, mass media, etc.', but unfortunately, there is no index of topics.

The first volume starts with a long multiple-chapter essay (pp. xxxix-cxxx) meant to provide a background of the Chinese minority in Indonesia. It calls attention to the group's history, the number of ethnic Chinese in Indonesia, their legal position through time, their educational status, the economic poli- 
cies that have affected them, and their contribution to Indonesia's national identity. The main text is divided into two parts. Part 1, 'Religion, social life and education' (vol. 1, pp.1-147), deals with the Chinese contributions to Islam, Buddhism, and the Three Teachings (Indonesia: tridharma, Chinese: sān jiào), Christianity, philanthropy, and education. Part 2, 'Language, literature and printed media' (vol.1., pp.149-379), focuses on their contributions to the Malay/ Indonesian language, the Sino-Malay literature, martial arts stories (cerita silat), literature in regional languages, the press and printed media (with special attention to renowned press personalities and female journalists), and publishing houses.

The second volume consists entirely of Part 3: 'Culture, arts and sports'. It deals with Chinese influence on local culture (kepeng coins in Balinese Hindu rituals, ceramics in Papua, and the Betawi culture), the batik expert Go Tik Swan, the film industry, wayang plays, dances, theatre and comedy, traditional music, western music, fine arts and comics, photography, fashion, culinary culture, traditional sports, and modern sports. More so than the first volume, the second volume frequently makes short excursuses to prominent contemporary Chinese Indonesians who excel in one of these fields. A recurring theme throughout the volume's chapters is the fact that the Chinese did not only introduce new cultural elements and adapt them to 'Indonesian' tastes, they were also prominently involved in western music, dances, and other forms of art. Indonesia's ethnic Chinese, in other words, took on the role of 'mediators of cosmopolitan culture' (vol. 2, p. 6o), from colonial times to the present.

The third volume is divided into three parts. Part 4, 'Science and technology' (vol. 3, pp. 1-19o), encompasses the contributions of Chinese Indonesians to the fields of traditional technology, building science and construction, traditional healing, modern medicine, natural science, law, the socials sciences and humanities, history, and economics and demography. Part 5, 'Economy, industry and trade' (vol. 3, pp. 191-314), calls attention to economic affairs, the batik industry, the industry of traditional medicine (jamu), the pharmaceutical industry, the clove cigarette (kretek) industry, real estate, and transportation. Part 6, 'Politics, governance and the military' (vol. 3, pp. 315-420), deals with the contributions of ethnic Chinese to Indonesia's anti-colonial resistance, political activities, governance, the military, and national heroes (pahlawan nasional). With some exceptions, most chapters of the third volume focus on relatively recent events, again providing ample snapshots of successful Chinese Indonesians. In the appendix, we find the original call for papers sent out in 2013 to the book's envisioned contributors (vol. 3, pp. 423-7), stating once more the purpose of this collaborative endeavor. Finally, short biographies of all the contributors are given (vol. 3 , pp. 428-56). 
Some chapters are based on (translations of) earlier work from the respective authors, which is understandable in a book project that aims to be comprehensive. The preface explicitly mentions that not every topic could have been covered (p. xxi). Yet, in light of the wide range of issues discussed, the reader would be hard-pressed to identify some of these omissions. Some readers would perhaps have liked a chapter on archaeological findings of Chinese influence in early Indonesia, or one on kuntau, the southern Chinese style of armed combat that influenced and in some regions became synonymous with local martial arts (silat). Even on the introduction into Indonesia of soy sauce (kecap), a full chapter could have been written. But, if there is one lesson to be learned from this book, it would be that the influence of ethnic Chinese on Indonesia's society has become so all-encompassing that relevant examples of 'contributions' - to stick with the book's parlance-are inexhaustible. From competitive swimming to chess and from show business to the feminist movement, one is bound to encounter ethnic Chinese featured alongside Indonesians of other backgrounds. In this regard, it is not unimportant to note that Tionghoa dalam Keindonesiaan was finalized in the time span of only 1.5 years, with the prospect that it was to be launched in August 2015 on the occasion of the seventieth anniversary of Indonesia's independence. A sincere (and realistic) hope is expressed that future scholars will find inspiration to delve deeper into any of the book's underexposed issues (p. xxi).

Tionghoa dalam Keindonesiaan targets three groups of envisioned readers (pp. xvi-xvii): 1) The Chinese-Indonesian community itself, so that they can look to the future with self-awareness and confidence in their heritage, 2) the non-Chinese Indonesians, so that they have a chance to understand their Chinese-descended compatriots beyond the realm of persistent stereotypes, and 3) Indonesia's educational sector, so that the Chinese community may one day show up in the nation's historical curriculum in a way that matches the contributions they have made to it. To my mind, there is an obvious fourth group to be added here: scholars. The book is, of course, of particular interest to Indonesianists. It is a delightful example of an edited volume written almost exclusively by cultural insiders. As such, reading Tionghoa dalam Keindonesiaan can be a welcome reprieve from the erudite onslaught in Indonesian Studies (as well as academia more generally) of western scholars conducting research through an Anglophone lens or theoretical framework that means very little to the actual people being studied. Rather, the book shows a community talking about themselves, eloquently. It deals with topics that matter to the contributors, while still maintaining detail and academic rigor.

Despite its richly designed layout, abundance of color pictures, and precise infographics, Tionghoa dalam Keindonesiaan is surprisingly affordable. It is 
well-edited; typos are remarkably few, and most Chinese, English, and Dutch words and names are spelled correctly. Nevertheless, some chapters suffer from inadequate page numeration, punctuation, and phonetic symbols. The choice to publish it in Indonesian has indeed been the best (and only) option. By doing so, this important work will be accessible to the vast readership of Chinese and non-Chinese Indonesians, as well as foreign scholars of the country whoone would hope-are all able to read the national language. Whether it will be noticed in the arena of China Studies depends fully on the availability of a Chinese translation in the not-too-distant future. This invaluable work certainly deserves it.

\section{References}

Jusuf, Iskandar (2014). Bangsa Tionghoa di perantauan jadi bangsa Indonesia suku Tionghoa. Tangerang: Penerbit Sekolah Terpadu Pahoa.

Mastuti, Dwi Woro Retno (2014). Wayang potehi Gudo. Seni pertunjukan Peranakan Tionghoa di Indonesia. Jakarta: PT. Sinar Harapan Persada.

Moerany, Watie (2014). Oey Soe Tjoen. Duta batik Peranakan Tionghoa Indonesia. Jakarta: Kementerian Pariwisata; Red \& White Publishing.

Oesman, Djono W. (2015). Tionghoa keturunanku, Indonesia negeriku, bangun bangsa tujuanku. Depok: Dwo Publishing House.

Pan, Lynn (ed.) (1999). The Encyclopedia of the Chinese Overseas. Cambridge, MA: Harvard University Press.

Santosa, Iwan (2014). Tionghoa dalam sejarah kemiliteran. Sejak Nusantara sampai Indonesia. Jakarta: Penerbit Buku Kompas.

Tan, Chee-Beng (2013). Routledge handbook of the Chinese diaspora. London: Routledge. Van der Molen, Willem (2017). 'Sajarah Cina: A nineteenth-century apology in Javanese', Wacana 18-2:402-421. 